\title{
7 Export restrictions in times of pandemic: Options and limits under international trade agreements
}

\section{Joost Pauwelyn ${ }^{1}$ \\ Graduate Institute, Geneva}

Dozens of governments have banned or limited exports of vital medical supplies and food. Are these legal under WTO and EU law? This chapter argues that while such bans are not allowed in normal times, the rules do not apply when the measures are justified on health grounds, are temporarily applied, and are aimed at preventing or relieving critical shortages of essential products. The only real deterrent to export bans is the threat of foreign retaliation that cuts off access to indispensable imports.

\section{More or fewer exports?}

In trade negotiations, exports have traditionally been seen as "good" (firms make money abroad) and imports "bad" (imports threaten domestic producers). In turn, many trade agreements focus on disciplining import barriers such as tariffs. To increase their own country's exports, the US reduces its tariff on Chinese cars while China cuts its tariff on US soybeans.

But what happens in times of coronavirus, when countries desperate for medical products such as personal protective equipment (PPE) restrict exports, not imports? Moreover, if PPE is to save lives locally, shouldn't an EU member-state government have the right to restrict their export? Or must EU solidarity play a role? And, shouldn't a country - such as Cameroon, which signed an Economic Partnership Agreement (EPA) with the EU have some kind of "access guarantee" now that it needs life-saving equipment from the EU that it cannot produce itself? As of early April 2020, 69 governments had banned or

1 I would like to thank David Kleimann and Gabrielle Marceau for precious comments on an earlier draft. All errors remain mine alone. 
limited exports of PPE, medicines, and other medical goods (see Gonzalez 2020), and economists have almost universally condemned the recent surge in export restrictions (e.g. Bown 2020, Evenett 2020, OECD 2020).

The key argument in this chapter is that international law currently provides a great deal of leeway (carve-outs and exceptions) to enact such restrictions, especially during a pandemic (see also Glöckle 2020). We briefly outline the options and limits when it comes to export restrictions under EU Law (both within and outside the EU), WTO agreements, and preferential trade agreements such as CETA and USMCA. For a more extensive discussion with specific references to the legal provisions and cases, see Pauwelyn (2020).

\section{Export restrictions under EU law}

Under EU law, EU Member States may rely on health exceptions for both intra-EU export restrictions and extra-EU export restrictions.

\section{Restrictions on "exports" within the EU}

Although the EU remains one of the most integrated common markets in the world, EU Member States retain the right to impose quantitative restrictions on exports to other EU Member States. However, the exception made on the grounds of "protection of health and life of humans" comes with certain conditions attached.

- Restrictions must have the legitimate aim of protecting public health.

- The exception has been narrowly interpreted and measures must be "proportional".

- Export restrictions should not "constitute a means of arbitrary discrimination or a disguised restriction on trade between Member States".

- Measures have to be well-founded and supported by evidence.

- The burden of proof in justifying export restrictions on health grounds lies with EU Member States.

\section{Restrictions on exports outside the EU}

EU institutions, in turn, have the power to impose export authorisation requirements for exports outside the EU, which "shall be free ... and not be subject to any quantitative restriction", except under certain conditions. 
- The EU Commission can impose export restrictions to "prevent a critical situation from arising on account of a shortage of essential products, or to remedy such a situation."

- Measures "may be limited to exports to certain countries or to exports from certain regions of the Union."

Individual EU Member States also retain the right to restrict exports to third countries on the grounds of "protection of health and life of humans". Here as well, "proportionality" applies, as when Romania recently announced restrictions on exports of certain agricultural products outside the EU: this was considered by the EU Commission as "not proportionate", since Romania had not provided evidence that it was facing shortages of agricultural products intended for human consumption (Durasin 2020). The country subsequently lifted the export restrictions (Marinas 2020).

\section{Export restrictions under WTO agreements}

The WTO, in turn, imposes a general prohibition on quantitative export restrictions and obligations of non-discrimination, publication, and notification. But it provides for an even broader range of carve-outs and exceptions:

- temporary restrictions for "critical shortages"

- measures "necessary" to protect health

- products in "general or local short supply"

- certain export restrictions on input materials to supply a domestic processing industry

- national security.

WTO export restriction obligations

a) General prohibition

- Outlaws "prohibitions or restrictions other than duties, taxes, or other charges ... on the exportation or sale for export of any product". Most export restrictions enacted in response to the current pandemic would probably meet this, since it is broadly worded and includes not only export bans, quotas, and export licenses, but also provisions for "other measures".

- However, GATT only prohibits quantitative export restrictions and not "duties, taxes or other charges" unless a given WTO Member included such commitment in its tariff schedule or accession protocol. Oddly, this implies that, whatever WTO members are prohibited from doing via quantitative export restrictions, they can still 
achieve by means of (largely unregulated) export duties. That said, in the wake of the COVID-19 pandemic, countries seem to have enacted only quantitative export restrictions, not export duties.

- The measure must have " $a$ limiting effect" on the amount of a product being exported. This "limiting effect" need "not be demonstrated by quantifying the effects of the measure at issue", e.g. via evidence that the actual amount of exports of face masks fell. Rather, such limiting effects "can be demonstrated through the design, architecture, and revealing structure of the measure at issue considered in its relevant context".

b) Carve-out for "critical shortages"

- As long as pandemic-related export restrictions are "temporarily applied", limited to foodstuffs or "essential products", and demonstrated to "prevent or relieve critical shortages", GATT should exempt such restrictions from the general prohibition.

- For export restrictions on "foodstuffs", the Agreement on Agriculture imposes advance notice, consultation, and due consideration of importing members' food security.

c) Non-discrimination, publication, and notification

- Subject to the exceptions below, export restrictions must be imposed on a nondiscriminatory (MFN) basis.

- They must also be administered "in a uniform, impartial and reasonable manner".

- When applying an export restriction, WTO members "shall aim at a distribution of trade (i.e. exports) ... approaching as closely as possible the shares which various (WTO Members) might be expected to obtain in the absence of such restrictions." For example, if a WTO member limits (but does not completely ban) the export of ventilators, it ought to aim at an allocation of ventilator exports between other WTO members that is as close as possible to the relative shares of ventilators that these other members imported before the export restrictions were imposed.

\section{WTO exceptions}

a) Measures "necessary" to protect health

- Any violation of GATT obligations set out previously can be justified on health grounds; even if the "critical shortages" carve-out does not apply and the prohibition on quantitative export restrictions were triggered, certain GATT articles provide a second line of defence.

- General exceptions allow for measures "necessary to protect human ... life or health". 
- Yet, health restrictions cannot be applied "in a manner that would constitute a means of arbitrary or unjustifiable discrimination between countries where the same conditions prevail, or a disguised restriction on international trade."

b) Measures "essential" to address "general or local short supply"

- WTO Members can take such measures, provided that all WTO Members are entitled to an "equitable share" of the international supply of such products.

- Measures must be "discontinued as soon as the conditions giving rise to them have ceased to exist".

- Restrictions may be justified when for example, protective masks are in "local short supply" in the regulating country, but possibly also when protective masks are in short supply generally or internationally and an exporting country (not itself in short supply) distributes exports of masks to wherever they are needed most.

c) Export restrictions on input materials to supply a domestic processing industry

Where countries are concerned about shortages or high prices of input materials, the exception allows for export restrictions on "domestic materials necessary to ensure essential quantities of such materials to a domestic processing industry", but only "during periods when the domestic price of such materials is held below the world price as part of a governmental stabilization plan".

d) National security exceptions

- A WTO Member can take "any action which it considers necessary" to protect "its essential security interests", including action "taken in time of war or other emergency in international relations".

- It is up to individual WTO Members to decide what "it considers necessary". In a recent dispute, a WTO panel reviewed a Russian transit restriction for compliance with GATT's security exception. Such an exercise remains very controversial.

- To date, WTO members have notified COVID-19 related export restrictions under "critical shortages" and health exceptions, not national security.

\section{Preferential trade agreements}

Other, less integrated, preferential trade agreements add little discipline to what is already in the WTO. For example, in the recently-concluded CETA between Canada and the EU, relevant GATT articles are simply incorporated. However, unlike GATT, CETA also prohibits export duties, though general exceptions apply (e.g. health, national security). 
The more recently concluded USMCA adds provisions regarding export restrictions on foodstuffs, in order to address concerns about food security (prior notification, consultation, and detailed explanation of export restrictions taken, time limits, and a prohibition on export restrictions on "foodstuff purchased for a non-commercial, humanitarian purpose").

\section{Conclusion}

"Trade saves lives" could have been the headline. COVID-19 hit so hard, quickly, and across borders, that many countries rushed to produce and import, while also imposing export restrictions on protective masks, ventilators, and other products they risked running out of.

Trade agreements generally prohibit quantitative export restrictions. But they also provide for a series of carve-outs and exceptions that explicitly allow countries, especially on a temporary basis, to restrict exports in times of pandemic, subject to certain conditions. In emergency situations like pandemics, the force of these legal constraints may be limited. Transparency, notifications, and consultations may be the best one can hope for (WTO 2020). The main deterrent for countries considering export restrictions in times of pandemic is most likely self-interest, including the realisation that export restrictions may cut-off their own supply chains, and that other countries may retaliate. At the same time, the EU's and WTO's legal strictures play an important role "in the shadow" of crisis. They can inform other countries, stabilise the situation, and avoid escalation. Once the crisis subsides, lessons can be learned, and rules and procedures potentially revised. 


\section{References}

Gonzalez, A (2020) "The G20 should expand trade to help developing countries overcome COVID-19," PIIE, 7 April.

Bown, C (2020), “COVID-19: Trump's curbs on exports of medical gear put Americans and others at risk", PIIE, 9 April.

Durasin, M (2020), "EU Objects to Romania's Move to Ban Agriculture Exports", Bloomberg, 11 April.

Evenett, S (2020), “Tackling COVID-19 Together, The Trade Policy Dimension”, 23 March.

Glöckle, C (2020), "Export restrictions under scrutiny - the legal dimensions of export restrictions on personal protective equipment", EJIL:Talk!, 7 April.

OECD (2020), “COVID-19 and International Trade: Issues and Actions", Joint statement by WTO Director-General Roberto Azevêdo and WHO Director-General Tedros Adhanom Ghebreyesus, 20 April.

Pauwelyn, P (2020), "Export Restrictions In Times Of Pandemic: Options And Limits Under International Trade Agreements".

Marinas, R (2020), "Romania lifts all wheat export restrictions -interior minister", Reuters, 16 April.

WTO Information Note (2020), Transparency - Why It Matters At Times of Crisis, and the WTO's dedicated website, "COVID-19: Trade and Trade-Related Measures", 7 April.

\section{About the author}

Joost Pauwelyn is Professor of International Law at the Graduate Institute of International and Development Studies in Geneva, Switzerland and Co-Director of the Institute's Centre for Trade and Economic Integration (CTEI). He is also the Murase Visiting Professor of Law at Georgetown University Law Center (since 2014). Previously he was Professor of Law at Duke University (2002-2007). He has also taught at Neuchâtel, Columbia, NYU, Stanford and Harvard law schools and worked as legal adviser for the WTO Secretariat (1996-2002). From 2007 to 2014, he was Senior Advisor with the law firm of King \& Spalding. 